\title{
(Re)Storying the Self: Exploring Identity through Performative inquiry
}

Marie-Heleen Coetzee

University of Pretoria

\section{Context ${ }^{1}$}

This paper investigates the ways in which the use of performative inquiry can shift notions of knowledge as situated ${ }^{2}$ to knowledge as experiential, embodied and an in situ encounter in the domain of performance studies. Specifically, this paper will focus on understandings of knowledge(s) around the articulation and construction of identity with particular reference to the production Shiftings (2007).

Shiftings was conceptualised as an extension of an undergraduate theoretical module that explores the ways in which contemporary theatre practices can position the performer as site/sight upon which hegemonic constructions of identity are played out, subverted or questioned. The production and working processes in preparing the production were prompted by students' perceived lack of identification with, and understanding of, the learning content.

Students claimed that there were no familiar points of reference in the learning material and that they thus do not understand the relevance of the learning material to their own performance practice, not to mention their everyday lives. They perceived the lack of definite answers in the module as contrary to their own experiences and interpretations of identity that were apparently organised around notions of stability, definite truths and a singular self. This perception was curious in the light of the social and political context in which students live and the ways in which they try to position themselves amongst their peers and in the world.

Considering that the predominantly critical and analytical modes of learning that the module requires are quite removed from the metaphoric, interpersonal kinaesthetic and visual modes of learning that drama students at the University of Pretoria seem to favour (Coetzee, Munro \& De Boer, 2004:140), students' reluctance to engage with the learning material was understandable. The students' learning preferences foreground the importance of the lived experience in the learning process. Their preference is supported by Merleau-Ponty's arguments as to the primacy of the lived, embodied experience in the construction of meaning, in knowing and in generating knowledge (Csordas, 1994:12). The 
challenge was thus to find a way of engaging with the module content that will personalise the learning content, foreground the lived experience and directly connect with performance practice. This implied that students needed to shift from viewing themselves as passive recipients of knowledge (viewing knowledge as situated) to positioning themselves as active agents in the creation of knowledge and meaning with specific reference to the course content. Such shifts will require that notions of the self, selfreflexivity and inter-subjectivity are foregrounded (a focus on ontological narratives ${ }^{3}$ ) in the learning process without undermining the academic integrity of the module.

To find a way of connecting academic discourse(s) as public narratives with ontological narratives in my teaching, I turned to autoethnography. Autoethnography traverses the domains of autobiography and ethnography, and has been used as a cross-disciplinary approach to writing, performance and research. The approach positions the self as witness to the process of constructing realities/reality; it positions experiential knowledge as "inseparable from the context of its production and reception" (Sutherland \& Acord, 2007:1); it connects the personal to the socio-cultural; and acknowledges the body as a "site of scholarly awareness and corporeal literacy" (A/r/tography online). Methodologically, it uses first-person narration, dialogue, emotional engagement with the research matter, autobiographical narratives and personal experiences to reflexively

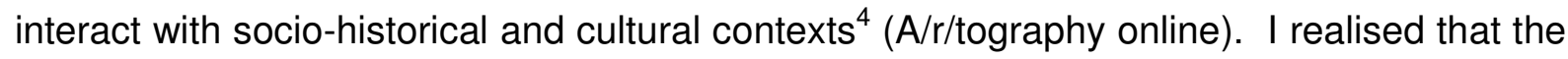
umbilical cord tying an autoethnographical approach to teaching and learning to the module content and performance practice is narrative and story. An overview of the module's understanding of narrative and story in the context of identity construction follows to demonstrate how this impacted on the personalisation, understanding and articulation of knowledge-as-lived-experience in and through the working process towards the production of Shiftings (2007) as well as the production itself.

\section{Storying selves}

The centrality of narrative in identity formation has been the focus of inquiry in many disciplines (Somers, 1994; Connelly \& Clandinin, 1990). Whilst older research read narrative as a representational form, current research situates narrative and narrativity as epistemological and ontological concepts with social implications (Somers, 1994: 606). According to Webster and Mertova (2007:2-3), narratives and the way in which we story them are powerful means of creating, enforcing or changing personal and social realities. Stories symbolise collective and personal pasts, presents and futures and they are layered 
with sensory, emotional and kinaesthetic references that stress the relational aspects of human existence. In the process of narrating stories, the narration constructs and delineates the parameters of our being-in-the-world, if not constitutes our being-in-the world. As Wiliams (1995:15) proclaims, "the self is made up of tales and images" and "we come into being through fantasy, we are at the root of its construction". Stories position people, and people are positioned through a network of other stories that shift in time and space (Somers, 1994:613 \& 621). As such, stories are always incomplete, becoming: incomplete as the process of storying is discontinuous.

How we construct and narrate personal stories relate to how we articulate and construct our identities (Grumet in Webster \& Mertova, 2007:9). How we narrate personal experiences and how we make sense of these experiences correspond to our beliefs about the world and ourselves. We shape stories to fit our identities and revise experiences to fit our stories (Somers, 1994:618). By reiterating personal stories, the storyteller's discourse "produces the effect that it names" (Butler, 1990:78). In this way the lives we live are the outcomes of the ways in which we narrated our lives. As Bruner (1987:15) points out, "we become the autobiographical narratives by which we 'tell about' our lives". This process of becoming is embodied - a storyteller not only tells/stories a self, but does a self. This notion speaks to Butler's ${ }^{5}$ re-interpretation of Austin's notion of the performative ${ }^{6}$. We become who/what we are by means of perpetually reiterating and citing conventionally determined acts and utterances that become normalised, internalised and an expression of the self (Butler, 1993:225). She sees reiteration as the "invocation of convention" (Butler, 1993:225) that gives acts of performing identity their binding power and, I argue, confirms hegemonic significations of identity. This suggests that performativity can perpetuate dominant discourses around a supposed core and stable identity that often determine the power relations between races, genders and classes. Butler further foregrounds the role of the body and embodiment in notions of performativity. She interprets doing or acting identity as dramatising the body, a "ritualized, public performance" (Butler, 1990:272, 277). Her notion of the performative questions the ideas of a fixed world beyond a performance of identity and problematises the delineation between the real $^{7}$ and the performed. I argue that her stance necessarily foregrounds the body as the site/site of becoming, of storying and of hegemonic signification with regards to identity. In foregrounding the body (and the self) as the site/sight of doing, uttering and becoming, storying becomes a performative act. 
The primacy of the lived experience in notions of performativity and in processes of storying positions the storyteller as the expert in his/her own life, thus foregrounding experiential, embodied knowledge, where subjectivity ${ }^{8}$ and partiality are key to constructing meaning (Webster \& Mertova, 2007:1;20-21). As stories shapeshift, so do we and in this way identity is perpetually constituted and reconstituted.

When storying and performing the self, individuals often attempt to present a unified narrative of self that resonates with notions of stability, certainty and continuity that stands in opposition to the self as becoming ${ }^{9}$ as evidenced in the initial response of the class to the learning content and echoed in the exploratory writing employed in creating the production:

'n Plek waar ek vir ewig kan wortel skiet. ...Alles op een plek. Bymekaar, stewig, konkreet. (Shiftings, 2007) ${ }^{10}$

The ideal of fixed identities leaves little room for change or for navigating shifting realities. The tension between the ambiguity experienced and the fixity imagined can result in individuals being overwritten by public/dominant narratives, a loss of voice, agency and loss of control over personal discourse:

I'm written into space with invisible ink. I've disappeared into this space - buried by my blurry memories. I am everywhere and nowhere at the same time. (Shiftings, 2007)

To draw attention to these tensions, an experiential, embodied process that recognises the autoethnographical impulse and makes visible the mechanisms of identity production needs to be constructed.

The questions remained as to how the autobiographical impulse can be used to foreground the interrelationship of public and private narratives, and how this interrelationship could be translated into a lived experience that consciously foregrounds personal agency in the construction of knowledge and meaning. This translation must necessarily speak to the interplay between performance and performativity. For me, the most obvious answer lies in autoethnographical performance. The juxtaposition of selves, acts of performance and performative acts, refracted embodiment and the conscious re- 
restorying of selves in a symbolic space can foreground processes of becoming and can draw attention to the "rhizomatic relationality" (Grauer, Beer, Xiong \& Bicke, [sa]:4) of identity construction.

Grauer, Beer, Xiong, Bicke and Springgay ([sa]:4) view rhizomes as:

interstitial spaces between thinking and materiality where identities and inbetween identities are open to transformations and people, locations and objects are always in the process of creation.

Spinggay's emphasis on incompleteness and interrelatedness resonate with the notion of identity as 'becoming' and demonstrates an awareness of both the public and ontological narratives that that the self journeys through. The notion of the rhizome offers a pluralistic way through which to access, and engage with, the various strands under investigation on a conceptual level.

The next challenge was thus to find a methodology for teaching and for engaging with performance practice that consciously engages with the autoethnological impulse and the rhizome. It is my contention that a reinterpretation of Fels and Meyer's (1997) methodology of performative inquiry, as organising principle of a teaching and learning experience and as a tool for engaging with performance practice, can interrogate and shape the relationship between public and ontological narratives in an experiential manner. It can further emphasise agency in the construction of knowledge and meaning; it can personalise the learning experience and fuse the aforementioned ideas in performance by means of stressing the interplay between performance and performativity.

\section{Performative inquiry}

Performative inquiry is a methodology for teaching and learning that harnesses and integrates body, mind and imagination (Fels, 1999). It explores the interfaces between performance, inquiry and experience in the context of specific environments, actions or phenomena, and positions these interfaces as sites for sense-making (Fels \& Meyer, 1997:76). Fels (1999) and Meyer (Fels \& Meyer, 1997) mainly apply performative inquiry in the domains of educational and process drama and as a cross-curricular teaching methodology. 
According to Fels and Meyer (1997:76), performative inquiry assumes that knowledge is embodied in creative processes and rooted in the "world of lived sensorial experience", taking cognisance of the fact that neither knowledge nor experience is a direct representation of the world. They view knowledge as an act of creation, as "bringing forth a world ... as part of living it" - a process similar to acts of performance (Fels \& Meyer, 1997:76). Performance is a tool for inquiry as it allows us to interrogate "our world(s) through creative and critical re-imagining" and in this process "(re)writing the landscape of knowing" (Fels \& Meyer, 1997:76). Performative inquiry holds that the enquiry and the phenomenon under scrutiny "co-emerge as iterative context" which contains inquirers and positions the inquirer as part of the context (Fels \& Meyer, 1997:76). In unpacking the above, it becomes clear that the emphasis in performative inquiry on the dialogical relationship between the inquirer and the phenomenon under investigation counters the notion of knowledge as situated and points to the possibility it offers to articulate rhizomatic relations within fields of inquiry. It positions knowledge and reality as constructs in which the self is the primary agent of sense-making. Thus, it supports notions of autoethnography and experiential learning.

Fels and Meyer's (1997:77) guidelines for conducing a performative inquiry focus on:

- deconstructing a phenomenon and finding "what matters";

- open generative spaces where alternative possibilities can materialise ("what if?");

- recontextualising the phenomenon by means of re-storying and symbolic worldcreation ("so what?").

In my case, the phenomenon would be identity as framed by the interplay between public and private narratives in the context of a theatrical performance. Although the aim of Fels and Meyer's (1997) use of performative inquiry is not to create a theatrical performance, it offers possibilities as a devising tool, especially when the autoethnographical dimensions of a performance are stressed (this will be discussed in greater detail later). Interestingly, Fels's and Meyer's understanding of the performative seems to stress the dimension of performance and thus do not offer a means of surfacing or rupturing the dominant performatives in identity constructs. Furthermore, although their explanation of performative inquiry suggests that narrative and/or story underpins symbolic worldcreation, their interpretation does not position narrative and/or story as a centrifugal force in the process of inquiry or learning. In order to surface the tensions between performance 
and performativity, and centralise narrative and story within a performative inquiry, I drew on elements of narrative inquiry to inform my reinterpretation of performative inquiry. ${ }^{11}$

Narrative inquiry provides a framework to look at the ways in which our experiences are depicted and structured through our stories (the importance of storying in shaping identity was addressed earlier), or at our renditions of our perceptions of these experiences (Webster \& Mertova, 2007:2). As "both phenomenon and method" (Connelly \& Clandinin 1990:2), it echoes understandings of performative inquiry. Narrative inquiry thus foregrounds the use of narrative, stories, telling and re-telling and repositioning identity in the process of inquiry. The elements of narrative inquiry that I fused with performative inquiry include various means of data collection, data coding, re-telling processes and reflective practices that I will discuss in more detail later (Narrative Analysis online; Connelly \& Clandinin, 1990).

My (re)reading of performative inquiry offered me the methodological approach I was searching for. My attempt to practically meet the challenges of the teaching and learning context $^{12}$ by using performative inquiry started by following Fels and Meyer's (1997:77) suggestion by finding "what matters".

\section{Deconstructing selves}

To start my performative inquiry, I selected concepts and terms that stemmed from the module content and that had the potential to connect to personal positions (threshold, home, journey, border, I, mapping, culture, belong, memory, etc.) and asked students to make free associations with the concepts/terms to create a springboard for discussions. Themes that arose from the discussions included a sense of alienation, rootlessness and uncertainty. To the students the figure of the refugee (stressing the nomadic aspects of the refugee experience) symbolised these themes. At the same time, students invested strongly in notions of cultural and personal stability, as manifested in their own backgrounds.

Following on the symbolism of the refugee, I gave students stories by refugees about their experiences of fleeing their countries of origin to take refuge in South Africa. The stories echoed the themes highlighted in students' discussions and struck an emotional cord in all the students. I used open-ended questions in an interview-style conversation to stimulate discussions about their strong emotional responses to the stories. We treated interviews 
as discursive acts (Narrative Analysis online). Themes that students identified from reading the stories of refugees included isolation, loss, crossing and re-crossing borders, homelessness, perpetual journeying, displacement, belonging and loss of a sense of self. (The initial discussions and writings were incorporated into the production as counterpoint to the supposedly fictive narratives created for the production). Students started to find thematic parallels between their own life stories and the stories of the refugees and cocreated 'visual-written' parallels in a piece of creative writing:

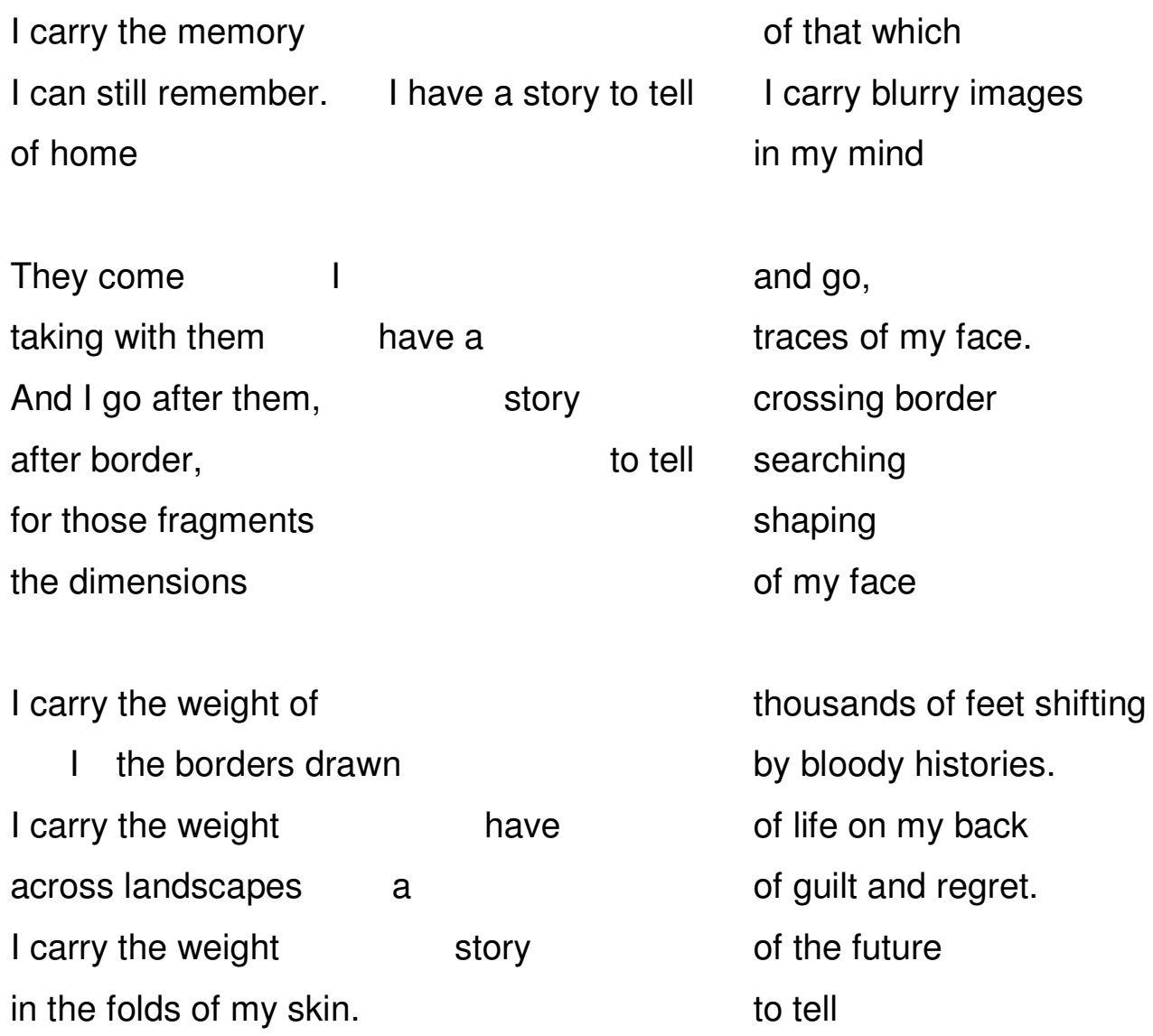

(Shiftings, 2007)

Through creative writing and lateral thinking exercises based on De Bono's (2007) principles, students responded in a variety of written ${ }^{13}$ and embodied modes to the stories and their emotional responses from various points of view, working through themes that they identified. I made use of process drama explorations to extend on, or gain, alternative perspectives on the themes and stories. Some exercises required students to story relationships between their own experiences and the experiences of others to further identification processes and to foster empathetic engagement by, for example, working with the loss and repossession of an object of personal value that they brought to the 
rehearsal process. In this way the relationality of ontological narratives surfaced. Students further responded in writing and in a series of freeze frames to the writing of others and even continued the stories that others began. They were also required to retell stories and experiences through various means to draw parallels between symbolic world-creation and personal world-creation and draw attention to the fictionalisation of experience in the act of storying. These writings and images were our field texts. ${ }^{14}$

I coded the field texts by tracing recurrent themes, symbolism and images in the writing and physical acts, identifying story-lines and narratives that interweave and interconnect, searching for what was left unsaid or for silences that became visible, located markers of identity, mapped continuities and discontinuities in the narratives and highlighted tensions that emerged. Students echoed this coding by visually depicting the rhizomatic network framing the field texts and by mapping their internal landscapes and framing the markers of identity through visual and tactile material inside suitcases that were later used as props in the production. ${ }^{15}$ The suitcases literally became deep maps that demonstrated how students storied themselves and the maps were revisited throughout the process. The lived experience is a perpetual process of modification (Connelly \& Clandinin 1990:4) that was reflected in students' mapmaking. The process of mapping did not aim to provide a solution to a process of inquiry, but presented a continual reformulation and repositioning of the inquiry into identity. These maps eventually determined the movement of characters through performance spaces and dictated the development of the central narratives and the sequencing of the scenes in the production.

Their stories narrated the ways in which their storied selves tried to make sense of themselves and the worlds they inhabit, traced their searches for constants amongst the flux of change, questioned the parameters of their existence:

Vir wie, vir wat? Wat wil ek weet? Wie is ek? Wat doen ek hier? ${ }^{16}$ (Shiftings, 2007)

The cyclical nature of these experiences and stories surfaced repeatedly and was described by one student as "never quite having left and never actually arriving" (Shiftings, 2007). This became a thematic and organisational principle of the production and the idea of repetition or return(s) a way of demonstrating the inexactness of situating the self and 
acts of performing the self, echoing aspects of performativity. This was also visible in students' maps and their embodied acts speaking to notions of self.

Their maps were thus interminable works-in-progress and as their understandings shifted and developed, so did the maps. This made visible the ways in which they understood identity (including language, a core self, class, race, gender) and the ways in which students chose to story themselves.

All of the writings foregrounded the notion of belonging and situated belonging as further markers of identity. Situated belonging included, amongst other things, geographical location, loved ones and communities/cultures - all of which refer to points of stability and continuity in understandings of identity:

a space where I can rest my weight, where I can breathe along with others, where my skin can blend in and my memories can settle. Where my fingerprints are visible and my foot can leave its print. (Shiftings, 2007)

To the students the corporeality of the body also signified permanence and a stable point of reference in understandings of identity, a pre-cultural phenomenon. Students' understandings of situated belonging were charted using visual and tactile stimuli both on their deep maps and in the performance space. The performance space was divided into three separate, self-contained areas with single access points. The first area was filled with sand, the second with water and the third with bark and pebbles. Each area symbolised an emotional and sensory relationship/response to the thematic content and to the markers of situated belonging that the students identified.

Recurrent images in the writing and maps included emptiness, baggage/burdens, shadows, footprints, being trapped, cross-roads (which spoke against the security that their narratives and markers of belonging promised). As stories were increasingly shared and collectively mediated, ontological narratives started to take on specific arrangements of metaphors, symbols, experiences, emotions and meanings related to the thematic content explored. All of the above formed the basis for the narrative, visual and kinaesthetic landscape (fictional) of the production and became the central reference point for navigating the narrative rhizome. 


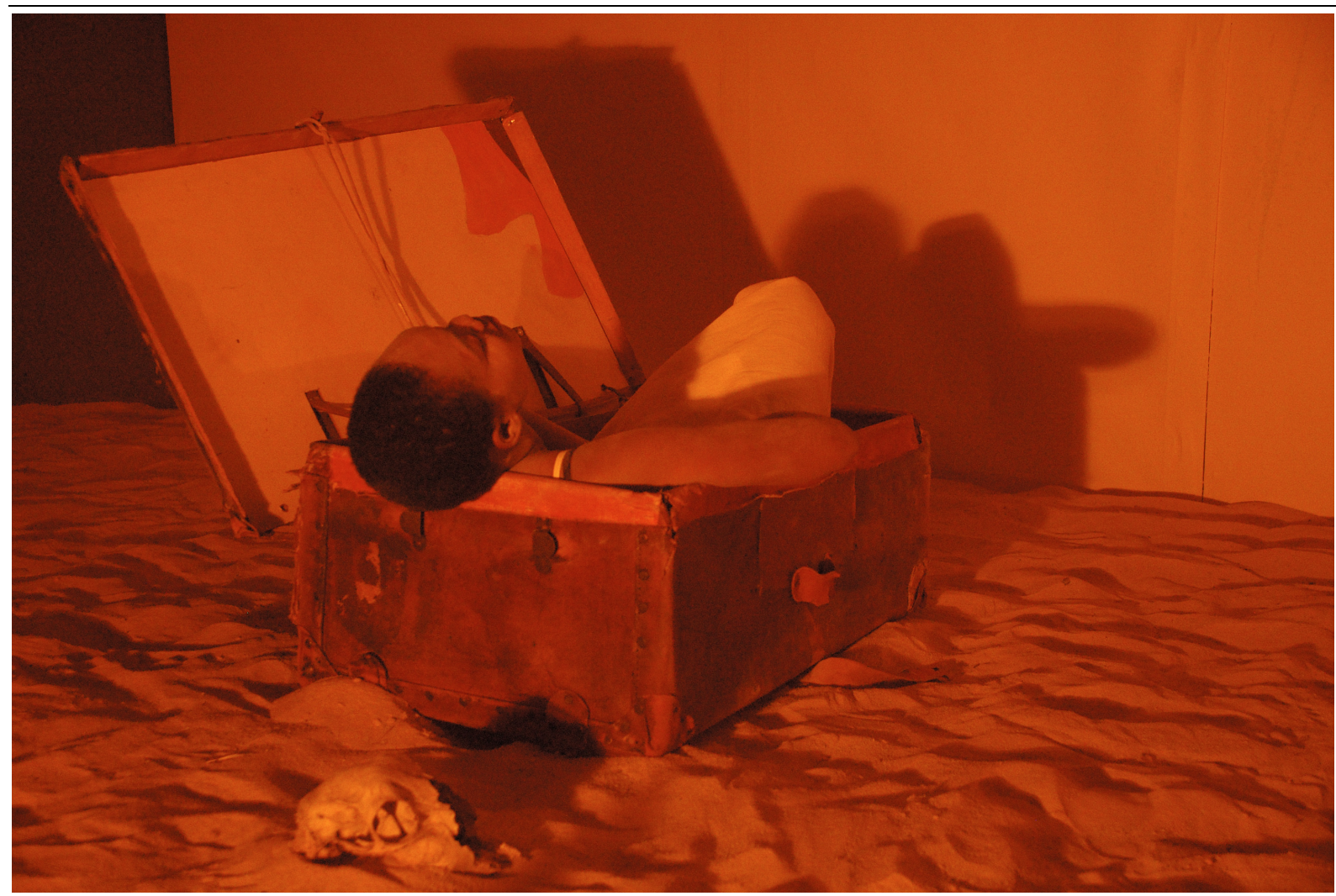

Photo 1 - The image of baggage finding its way into the performance

The tensions, discontinuities and disjunctions between their experiences and their perceived points of stability were brought to consciousness through depicting these visually (on the maps). These disjunctions also formed the basis for performer relationships and the idea of a narrative and visual collage as organising principle of the production. They further manifested in the interrupted language and fractured narratives that characterised the eventual production. Through their active identification with ideas central to the refugee experience, students could decisively 'story' themselves into a production. In doing so, and in fusing their ontological narratives with the narratives of others, they blurred the lines between the real and the not-real that opened up a space in which performativity could later be interrogated.

Finding "what matters" engaged with the autoethnographical impulse in "articulating the intersections of peoples and culture[s]" and introduced the notion of a "migratory identity" (A/r/tography online) that problematised the stability of national, cultural and personal identities. The conscious, autobiographical investment in the process of storying brought attention to the process of storying per se and to the idea of storying a self. At this stage interpretations of a singular self whose lived experiences, emotions and actions were 
embodied through the body as stable locality were still prevalent. To re-imagine such interpretations and involve more of the module content, I had to turn to Fels and Meyer's (1997:77) "what if" and "so what".

\section{Imagination and revisitation}

We explored the last two phases of performative inquiry as overlapping phases in the context of devising a production. The multiple visual representations mentioned earlier, interspersed between writing and physical explorations, reflected the meanings of student's personal experiences in relation to the central themes explored and became the starting point for envisioning alternative possibilities and meanings related to the self and to narrative constructions. To more directly connect to the module content, some tasks required of students to literally map their personal journeys and their experiences of them in relation to the performance spaces identified on a piece of paper that held an enlargement of their personal footprint. Students unpacked their choices of journeys, starting places, where they felt they belonged or not, etc. in the context of the overarching themes through various modes. In line with autoethnographical approaches, these modes included (amongst other things) elements of movement and physical theatre, story-telling, autobiography, poetry, reflective writing, creative writing, dramatic dialogue and multimedia to explore (and make sense of) the thematic content they interrogated. These modes were also used later in the production for similar reasons.

They further had to match the academic arguments central to the module to their maps. In the process it became clear that they started questioning the initial certainty about their identities and started to identify more strongly with the symbolism of the refugee figure:

I can't remember how long I had been going. Can't recall where this journey began, how many borders I had crossed to get here or where along the way I had lost the map. (Shiftings 2007)

In constantly revisiting the deep maps that they created, they recognised the idea of a migratory identity, transformation and the incompleteness of self and locations. Significantly, they also started recognising instability in markers of identity: 
Ek het herrineringe saam met my gedra sodat ek kon seker wees van waar ek was. Die gesigte van die mense wat die roete sou aanwys. Al probleem is, ek kan nie onthou waar ek dit gesit het nie. (Shiftings 2007). ${ }^{17}$

This experiential understanding of the academic perspectives (public narratives) addressed in the module assisted in personalising the learning content. The mapping and matching also literally depicted their journeys through the rhizomatic relationality of their ontological narratives and the public narratives that framed these narratives. They were asked to project multiple positions, experiences, stories and selves into the performance spaces and create future visions and alternative narratives from that. The focus of the storying shifted from rehearsing the past to the "current context of the telling itself" (Auburn, 2005), demonstrating narrative reflexivity

and bringing about a shift in subject position. Symbolic world-creation, which is an integral part of performance, opens up a safe space where becomings can be imagined, tested and performed.

In order for performers to meaningfully engage with the learning opportunities that symbolic world-creation offers, they needed to construct an embodied, storied presence that performs this world. Students became personifications of ideas, arguments, concepts and emotions in relationship to other ideas and emotions, rather than defined characters. The collision/collusion of roles, perspectives, emotions, themes, contexts and imagery drove the development of the narratives, rather than plot progression. This choice offered them the opportunity to represent multiple and shifting points of view (thus constantly shifting subject positions), juxtaposed with their personal points of view. It created distance between themselves and their deliberately storied selves that were interrupted by other narratives and stories. Role-taking fuses the self with adopted positions and narratives, again obscuring the distinction between the real and the not-real. I argue that this fusion between the real and not-real, facilitated by role-taking, is a generative moment of learning and self-reflection that operates in an in-between space. The positioning and repositioning of subjectivity in this space stresses the discord between the personal, perspectival and scholarly thinking/knowledge(s). The spaces between the actual performance spaces are significant in this regard as the physical in-betweenness became framed as a conceptual and transformative space that allowed alternative understandings and positions to materialise. 


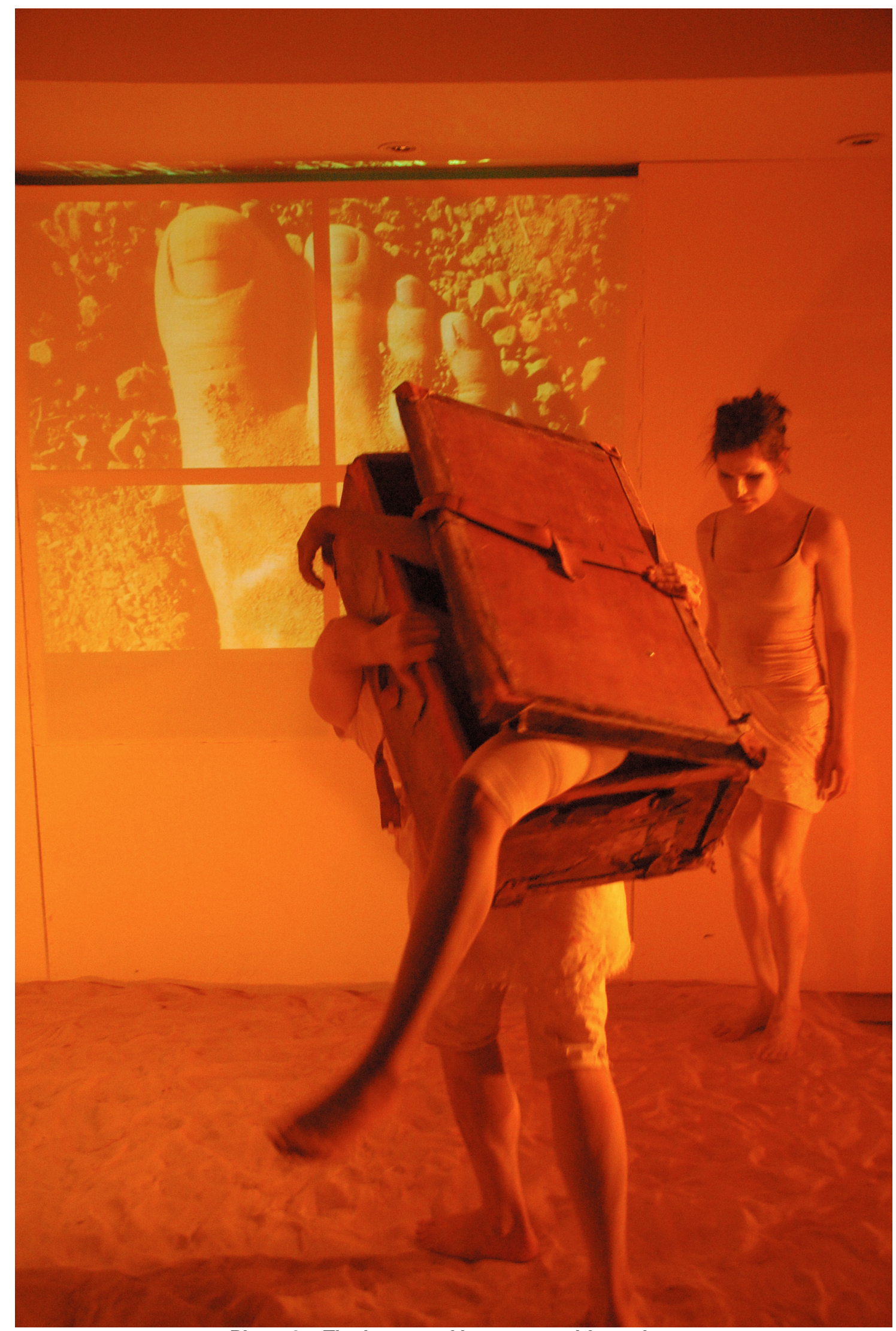

Photo 2 - The images of baggage and footprints 
Furthermore, the double consciousness that role-taking facilitates (the self in relation to the role) creates constant tension between the real and the not-real, creating distance between the person and what the role represents and embodies. Although role-play may actually reveal a person rather than conceal a person (Hornbrook 1998:117), it is precisely these permeable boundaries of being that produce self-awareness and self-reflexivity.

Role-taking in this context physically demonstrated knowledge as an experiential encounter. Perpetual shifts in voice from $1^{\text {st }}$ person to $3^{\text {rd }}$ person juxtaposed with a consideration of the autoethnographical undertaking itself shows that there are multiple accounts of experiences and versions of the self (Seamen, 1999:2), creating a confluence of dynamic, storied selves. In transposing ideas to the performance space (the symbolism of this space has already been discussed), I asked students to attach pieces of text that summarised the crux of each part of their emotional journeys to the map and to draw symbols representing their emotional connections to the symbolic space and the text on their maps. The only conditions were that they have to end where they began (to reflect the cyclical nature of their experiences, stories and journeys mentioned earlier). Some change must be apparent upon their return to the starting point to acknowledge their understanding of a migratory and shifting identity.

In response the above explorations, the spaces gained multiple access points and performers were to continually cross and re-cross into the various performance spaces, carrying overlapping, discontinuous and contradictory narratives. The three main performers moved through all three performance areas, some of the other performers also moved through all three spaces (some more than once), some used two of the spaces and one remained in the same space throughout the production. All three performance spaces were to be simultaneously inhabited, and entries and exits did not happen concurrently. The narratives were thematically ordered, fractured time, space, causality and presented shifting subject positions. In his way narrative line and unity were ruptured and notions of continuity of narrative traditions (whether ontological or public) were destabilised. The movement of performers through space (or not) speaks to their journeys of searching and discovery; of where they aimed to locate themselves in constantly shifting physical, emotional and conceptual terrains; truths, and their gradually altering insistence on fixed positions: 
And so we try to find a place in which we can be still and maybe get bearings that help us to understand where we are where we came from and where we are going. We try to hold steadfast to something that appears to outlast this constant creation and destruction, the inevitable aging, the moving through and the moving on, the indefinite dying and creation. This stable something I call my home. Where/what is it?

The suitcases that they carried (or were carried in) across performance spaces served as constant visual and tactile reminders of their deep maps, encapsulating the lived experience of storying and re-storying that characterised the creation of the maps (and the production). The constant shifting through space and the simultaneity of the dramatic action in different performance spaces in the eventual production created a sense that images, actions, sounds and realms of narrative are fused. Students emphasised the cyclical aspects of narrative and experience (and identity) by stringing together "short, fairly discrete units of composition" (Porter in Elbow, 1998:4) with a common theme and a sense of circularity similar to a crot in literature, to construct the production. The crots presented snapshots of experiences and understandings from multiple perspectives, in multiple languages, to be considered simultaneously within the temporal limits of the production.

As performers literally moved through the in-betweens in the performance space, they shifted position, perspective and selves. Crossing the threshold into another performance space signified entering another realm of understanding and another conceptual level. Understandings/selves drawn from previous crossings infused some interactions between performers and the content explored in the next performance space, gradually increasing the complexity of understandings and overlaps, and layering ontological narratives becomings.

In embodying and envoicing these becomings in performance-based explorations and in their performances the deliberate fusion between acting and actuality was foregrounded by juxtaposing the real and the not-real on the same site (the body). Performative signifiers characterised positions, roles, selves and conceptual/emotional shifts that would become more layered (and dissonances between overlaps more articulated) as the production progresses. The repetition of performative acts and acts of performance, whether in acting or actuality, cannot be exact (Pollock, 2005:11). Performing performativity drew attention 
to the discord between the sign and the referent, by amplifying the discordances that performativity seeks to erase. Foregrounding this tension in a theatrical performance disrupted the supposed stable, pre-cultural, material boundaries of the body that supports the continuity of performative bodily acts which confirms notions of a fixed core identity. Consciously engaging with performativity in performance further positioned performance and the body as both a "reflexive space" and a reflexive site (Pollock, 2005:1) that allowed for a continuous oscillation between ontological and public narratives and for questioning identity constructs:

Strange things, fingerprints. Makes me faceless, genderless, nameless. Yet they call it my identity. (Shiftings 2007)

The finger was representative of the body as a whole and in the context of identity as inconstant, the stability of the body as marker of identity was problematised.

The performance of supposedly known and stable self in relation to perspectives that the scholarly content of the module proposed, and alternative selves, further drew attention to identity as performed construct. The materialisation of this realisation was dependent on the expression and performance of the stable self so as to stretch the boundaries of what students' accept to be their world until they ruptured it and the alternative possibilities/understandings offered by the symbolic world surface amongst the ruptures (symbolically, metaphorically and physically). In this way interpretation gaps ${ }^{18}$ that $^{2}$ destabilised dominant discourses and hegemonic significations were opened up, thus demonstrating the storying and performing of identity. I argue that the overlaps that performance facilitates (including real/not-real, performance/performativity, public/ontological narratives, symbolic/real world) confirm the in-between space I discussed earlier and heighten awareness of the act of construction of that which overlaps. Furthermore, it draws attention to interpretative gaps and so lays bare the ideological underpinnings of both worlds (which supported the module content). The act of creating the performance and performing made visible the "disciplinary stratagems" that determine, constitute and naturalise identity constructs (Diamond cited in Pollock, 2005:11). By recognising these stratagems and interpretative gaps, students saw possibilities for change, the materialisation of alternative identities and for storying these into being. 
In the moment of uttering, embodying, visualising, representing and doing, students became the imaginings of the utterance/action and the ideas that they summon. In doing so, the possibility of an alternative becoming implies a "contingent construction of meaning" (Butler, 1990:139) that was continually negotiated and embodied in relation to public narratives.

Future audiences represented public narratives and the knowledge(s) that inform these narratives. To acknowledge the instability of these narratives, they decided to let audiences also move between performance spaces. In entering different spaces, the relationship between audiences and performers, and what they represent, can continually shift and are renegotiated. To demonstrate the rhizomatic relationality of ontological and public narratives, the audience was to be divided into three to follow one of the three main performers on their journeys in and out of performance spaces. As space shifted, so did time, perspective, forms of discourse, atmosphere, role, mode of performance and visual imagery. This, together with the crots, created further rhizomatic relations in that the audience and performers were required to access conceptual and emotional spaces through multiple entry points offered by the production and navigate those spaces in the absence of conventional ordering devices.

By following one performer, audiences saw only one character's story unfold during a performance. To see the whole, the audience had to see all three stories, emphasising the partiality, perspective-dominated nature and incompleteness of knowing and experience. In the process of performance the moving also impacted on the spaces and altered the physical appearance of the spaces (water splashing onto the floor, sand shifting and changing shape, etc.), which emphasised temporality and change. Moving between physical spaces and weaving through multiple and overlapping narratives to map coevolving wor $(\mathrm{I}) \mathrm{ds}$ challenged the view that knowledge is situated. As a student's reflective writing proclaims:

It [Shiftings] was a place of transformation. Meanings changed as we infused them with what we wanted or needed them to.

Audiences actively engaged with identity construction and the overlaps between the symbolic and real worlds by giving fingerprints before entering one of the performance spaces (see quotation in this regard earlier) and by seeing some of the means by which 
the production was created, namely the words that I used to start the devising process and pieces of writing that demonstrated performers' engagement and identification with the thematic content. This was interspersed with spaces in the production programme where they could reflect on their own understandings and experiences as the production progressed.

For the performers the production acted as a framing device to articulate and engage with knowledge of identity formation by means of an experiential, conscious re-storying of the self and by fusing ontological layers and narratives:

Without directly meaning to, much of what came from me was autobiographical and came from the loss of my best friend... When he suddenly died, so did my map of the world. The space for creation was a space in which I could deal with his death in a new way, from a different perspective - and a space which allowed me to voice it out into the world in a renewed way. I watched my story - and the stories of all of us - become something new and different.

The duality of the students/roles, performance/performativity and real/not-real created a dynamic and constant tension that simultaneously fed awareness and reflection inside and outside the symbolic world. This meta-cognitive position supported my aims for teaching and learning in the module.

\section{Conclusion}

Performative inquiry, as an approach to teaching and learning, offered a way of accessing the public narratives foregrounded by the module via students' ontological narratives. In foregrounding inter-subjectivity and selfhood in the context of the module content, the learning content was personalised. The juxtaposition of inquiry, experience, creation and performance that the performative inquiry approach offered gave students a space to cross and re-cross performative thresholds that made visible the contingent and relational aspects of identity formation, thereby shifting students' understanding of identity. This enabled them to question their initial interpretation of their identities and to (re)construct their "systems of knowledge" (Jones, [sa]:8) by "rebuilding, rearranging our sense of self every moment" (as a student commented in the reflective writing). 
Stressing multiple 'l's allowed students to acknowledge, and speak as, multiple selves, yet integrating these selves in the moment of doing and uttering and framing that was a simultaneously reflective experience in the frame of the performance. The performative inquiry thus allowed students to embody multiple reflective stances. The multiple overlaps in modes of engagement with the process of the performative inquiry allowed performers to self-reflexively prolematise identity and their subject position(s); recognise the performative aspects of identity; and make visible the mechanisms of identity construction. The performative inquiry positioned students as witnesses to the ways in which they became active agents in generating knowledge.

My reinterpretation of performative inquiry offered me an appropriate methodological approach to teaching and learning that served the students' learning preferences and the demands of the module. It made use of narrative as central force in performance and identity constructs to offer a personalised, experiential, embodied engagement with knowledge. It demonstrated how conceptual and academic thinking translates to performance practice. The performative inquiry not only made it possible for students to come to terms with the course content, but encouraged them to re-position, re-iterate and re-imagine themselves in/and their wor(I)ds.

\section{Notes}

1) I would like to thank the SATJ peer-reviewers for their helpful comments.

2) Situated knowledge refers to a perception of knowledge as contained, departmentalised, and separated from its means of production and reception (Sutherland \& Acord 2007:1).

3) Ontological narratives are the kinds of stories people tell to make sense of, and act in, their lives (Somers 1994:618).

4) The use of the self as the main source of data has been criticized for being overly subjective. I would argue that the principle holds as he conscious use of distancing mechanisms can allow for an informed research perspective.

5) Although Butler specifically refers to gender identity, the principles of her interpretation of performativity can be generalised to a broader context.

6) Austin's notion of the performative points to the ways in which utterances do something in the world, not merely describe actions or generate consequences. Such words are actions in themselves and has the ability to affect, to bring about change. Not only can these utterances make a difference in the world, they have the power to create a world (Loxley 2006:2).

7) For the purposes of this article, the 'real' refers to a personalised and mediated construction, experience and interpretation of the physical world in contrast to the consciously created fictional and symbolic world inside a theatrical production.

8) At the same time, the celebration of subjectivity is a prominent point of critique levelled against narrative inquiry (Webster \& Mertova 2007:20).

9) This notion is echoed by Webster and Mertova (2007:17) in their discussion of Western science's longing to discover "one true story" that seeped into dominant worldviews and thus influence our storying.

10) A place where I can take root forever. ...Everything in one place. Together, sturdy, concrete.

11) Although the methodology is generally associated with the discipline of psychology, I posit that elements of narrative inquiry can inform performative inquiry by providing tools through which to realise a performative inquiry. 
12) Logistical and practical constraints, together with voluntary participation dictated the choice of, and number of, performers. Seven performers, most of them enrolled for the module and took part in the production. The production was a public performance.

13) Following Connely \& Clandinin (1990:5-6), this included letters, journals, notes, autobiographical and biographical writing. In my process, it also included drawings.

14) Field texts or field notes refer to data, reflective notes on the data, alternative perspectives on the notes. It can take many forms and articulates with the context of the particular exploration, experience or observation (Connelly \& Clandinin 1990:5-6).

15) Borrowed from Clatchery's 2006 publication The Suitcase Stories: refugee children reclaiming their identities.

16) For whom, for what? What do I want to know? Who am I? What am I doing here?

17) I carried memories with me so that I could remember where I was. The faces of people who were to show me the way. The problem is that I can't remember where I placed them.

18) My understanding of interpretation gaps is based on the Greek term "aporia", which points to the instability of terms that cannot be reduced to an interplay between binary opposites. (Macey 2000:18).

\section{References:}

A/R/TOGRAPHY. [sa]. http://m1.cust.educ.ubc.ca/Artography/journal art.php Accessed 12/03/2007.

AUBURN, T. 2005. Narrative reflexivity as a repair device for discounting 'cognitive distortions' in sex offender treatment. Discourse \& Society, 16:5, 697-718. Abstract at http://das.sagepub.com/cgi/content/abstract/16/5/697

BRUNER, J. 1987. Life as Narrative. Social Research. 54: 1-32.

BUTLER, J. 1990. Gender Trouble: Feminism and the Subversion of Identity. London: Routledge.

BUTLER, J. 1993. Bodies that Matter: On the Discursive Limits of "Sex". London: Routledge.

CLACHERTY. G. 2006. The suitcase stories: refugee children reclaim their identities. Cape Town: Double Storey Books.

COETZEE, M-H, MUNRO, M \& DE BOER, A. 2004. Deeper Sites through various Lines: LMS and whole brain learning in body/voice training for performers in the HET band. The South African Theatre Journal. 18:134-157.

CONNELLY, M \& CLANDININ, F. 1990. Stories of Experience and Narrative Inquiry. Educational Researcher. 19(5):2-14. http://www.jstor.org/stable/pdfplus/1176100.pdf. Accessed 12/04/2007.

CSORDAS, T. (ed). 1994. Embodiment and experience: the existential ground of culture and self. Cambridge: Cambridge University Press.

DE BONO, E. 2007. How to have creative ideas. London: Vermillion.

ELBOW, P. $1998 . \quad$ Collage: Your Cheatin Art. scholarworks.umass.edu/context/peter elbow/article/1014/type/native/vie wcontent. Accessed 12/09/2008.

FELS, L. 1999. In the wind clothes dance on a line: performative inquiry - a (re)search methodology possibilities and absences within a space-moment of imagining a universe. Ph.D dissertation. The University of British Colombia. Vancouver, Canada. http://www.nursing-informatics.com/PhD/LynnFels dissertation.pdf. Accessed 12/03/2007.

FELS, L. \& MEYER, K. 1997. On the Edge of Chaos: Co-evolving world(s) of Drama and Science. Journal of Teacher Education. 9(1):75-81.

HORNBROOK, D. 1998. Education and dramatic art. London: Routledge.

IRWIN, R, GRAUER, K, BEER, R, XIONG, G, BICKEL, B \& SPRINGGAY, S. [sa]. The Rhizomatic Relations of $A /$ r/tography. Accessed 28/05/2008.

http://cust.educ.ubc.ca/whatsnew/Papers/STUDIES\%20-\%20EXHIBITION\%20D.pdf

JONES, K. [Sa]. Narrative researchers in search of an aesthetic: the use of arts-based representations in the diffusion of biographic data. http://www.qualitativesociologyreview.org/ENG/index eng.php Accessed 20/08/2008.

LOXLEY, J. 2007. Performativity: a new critical idiom. London: Routledge.

MACEY, D. 2000. The Penguin dictionary of critical theory. London: Penguin Books.

MUNRO, M \& COETZEE, M-H. 2007. Mind the gap: beyond whole-brain learning. South African Theatre Journal. 21:92-108. 
NARRATIVE ANALYSIS. [sa]. http://faculty.chass.ncsu.edu/garson/PA765/narrativ.htm. Accessed: 30/08/2008.

POLLOCK, D. 2005. Remembering: oral histories and performance. New York: Palgrave Macmillan.

SEAMEN, M. 1999. Performing the self in Australian documentary film. http://www.aber.ac.uk/ imcwww/ldentact/Papers/paper32.doc. Accessed 16/08/2008.

SHIFTINGS. 2007. Devised by Coetzee, M-H, Graf, A, Motau, R, Callan, A, Van Graan, C, Shounyane, T, Viljoen, D \& Wolmarans, J. Unpublished text, University of Pretoria, Pretoria.

SOMERS, M. 1994. The narrative construction of identity: a relational and network approach. Theory and Society 23:605-649. http://www.jstor.org/stable/pdfplus/658090.pdf. Accessed : 20/08/2008.

SUTHERLAND, I \& ACORD, S.K. 2007. Thinking with art: from situated knowledge to experiential knowing. Journal of Visual Art Practice. 6(2):125-140.

WEBSTER, L \& MERTOVA, P. 2007. Using narrative inquiry as a research method. New York: Routledge. 